\title{
Wealth Effects in a Cash-In-Advance Economy
}

\section{Eric Kam}

Ryerson University

\section{Paul Missios}

Ryerson University

Kam, E., \& Missios, P. (2003). Wealth effects in a cash-in-advance economy. Economics Bulletin, 5(2), 1-7.

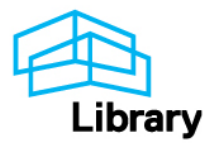




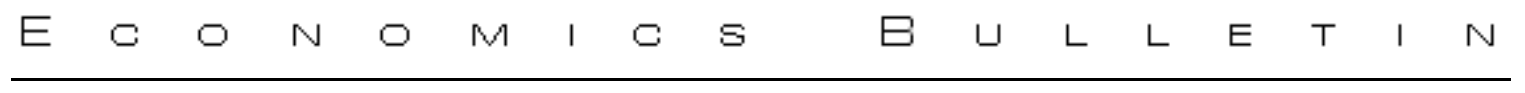

\title{
Wealth effects in a cash-in-advance economy
}

\author{
Eric Kam \\ Ryerson University
}

\author{
Paul Missios \\ Ryerson University
}

\begin{abstract}
This paper examines the monetary growth implications of combining Stockman's cash-in-advance constraint on consumption and capital goods and an endogenous rate of time preference that is an increasing function of real wealth. The cash-in-advance constraint imposes an investment tax that reduces steady state consumption and capital. However, endogenous time preference wealth effects link the real and monetary sectors to yield a Mundell-Tobin effect. Cash-in-advance constraint effects dominate endogenous time preference wealth effects so that monetary growth reduces steady state capital and consumption.
\end{abstract}

\footnotetext{
We wish to thank Avi Cohen, David Laidler, Arman Mansoorian, Bill Scarth, John Smithin and an anonymous referee for their comments. The standard caveat applies.

Citation: Kam, Eric and Paul Missios, (2003) "Wealth effects in a cash-in-advance economy." Economics Bulletin, Vol. 5, No.

2 pp. 1-7

Submitted: January 14, 2003. Accepted: March 30, 2003.

URL: http://www.economicsbulletin.com/2003/volume5/EB-03E00001A.pdf
} 


\section{Introduction}

Stockman (1981) imposes a cash-in-advance constraint on purchases of consumption and capital goods, and consequently monetary growth acts as an investment tax, which lowers the production and demand for steady state consumption and capital. More recently, Kam (2002) models the rate of time preference as an endogenous function that depends positively on real wealth. The resulting wealth effects link the monetary and real sectors, converting savings into steady state consumption and capital. This paper demonstrates that the cash-in-advance constraint effect dominates endogenous time preference wealth effects. Monetary growth decreases steady state consumption and capital, which reverses the real sector implications of the Mundell-Tobin effect.

The optimizing underpinnings of the infinitely-lived, representative agent model have been integrated into several macroeconomic applications over the past four decades. ${ }^{1}$ One standard assumption is that the rate of time preference and the discount factor applied to the lifetime flow of utility are exogenous. This assumption is responsible for many of the limiting conclusions obtained in this framework. Specifically, it implies monetary superneutrality by fixing the real interest rate and the marginal product of capital, which removes the link between the real and monetary sectors and insulates the capital stock and consumption from the effects of monetary growth (Sidrauski 1967a,b).

Uzawa (1968) is an attempt to endogenize time preference and derive a more general representation of behavior. However, this time preference specification has been criticized and generally dismissed because of the assumptions necessary to ensure steady state stability. ${ }^{2}$ Uzawa models time preference as an increasing function of instantaneous utility, which itself depends positively on current consumption. Saving is modeled as an increasing function of real wealth, which implies that the representative agent becomes increasingly impatient as consumption increases. This representation of behavior is counterintuitive and also contradicts the theory of savings as a decreasing function of wealth. ${ }^{3}$

A rate of time preference that is an increasing function of real wealth resolves the counterintuitive preference criticism, permitting microeconomic foundations to generate a monetary growth model that is characterized by steady state stability and the Mundell-Tobin effect. Monetary growth yields substitution effects that lower the initial value of real wealth and raise the opportunity cost of holding real balances. This lowers steady state real balances and the rate of time preference but augments savings. Endogenous time preference wealth effects reinforce the substitution effect and convert additional savings into steady state consumption and capital. Optimizing behavior induces interdependence across time preference, wealth and savings so that the Mundell-Tobin effect is the result of reinforcing substitution and wealth effects, which has recently been empirically verified by Woodward (1992), Shrestha et al. (2002), and Rapach (2003).

This paper analyzes the monetary growth implications of simultaneously modeling two contradictory effects: first, a continuous-time, monetary growth transformation of Stockman's cash-inadvance constraint on the purchase of consumption and capital goods; second, an endogenous rate of time preference that is modeled as an increasing function of real wealth. The following section derives the monetary growth implications of the representative agent model with this endogenous time preference. Section 3 considers the implications of combining this time preference specification

\footnotetext{
${ }^{1}$ For a comprehensive review of monetary growth in representative agent models, see Dornbusch and Frenkel (1973) and Wang and Yip (1992).

${ }^{2}$ Blanchard and Fisher $(1989,74-5)$ argue, “... the Uzawa function, with its assumption (that the rate of time preference increases in instantaneous utility) is not particularly attractive as a description of preferences and is not recommended for general use."

${ }^{3}$ For the latter, see Mundell (1963), Tobin (1965), Laidler (1969), Begg (1980) and Epstein and Hynes (1983).
} 
with a cash-in-advance constraint on the purchase of consumption and capital goods. The critical result is that the cash-in-advance constraint effect dominates endogenous time preference wealth effects so that monetary growth reduces steady state consumption and capital. Section 4 offers concluding comments.

\section{The Representative Agent Model with Endogenous Time Pref- erence}

Consider a monetary growth model in which real balance holdings do not yield utility but appear in the definition of real wealth and the asset accumulation identity. Assume that the discount factor that is applied to future streams of utility is

$$
\beta(v)=\int_{0}^{t} \theta_{v}\left(a_{v}\right) d v
$$

where $v$ is a time index and $\theta$ is the rate of time preference that is assumed to be an increasing function of real wealth $a$. The representative agent maximizes

$$
\int_{0}^{\infty} u\left(c_{t}\right) e^{-\int_{0}^{t} \theta_{v}\left(a_{v}\right) d v} d t
$$

where $c$ is consumption, ${ }^{4}$ and faces two flow budget constraints

$$
\begin{gathered}
\dot{a}_{t}=f\left(k_{t}\right)+x-c_{t}-\pi_{t} m_{t} \\
a_{t}=k_{t}+m_{t}
\end{gathered}
$$

and a stock budget constraint

$$
\lim _{t \rightarrow \infty} a_{t} e^{-\int_{0}^{t} r_{v} d v} \geq 0
$$

where $f$ is a constant returns to scale production function, $k$ is the capital stock, $x$ is the real value of government transfers that maintain constant real balances following an inflationary period, $\pi$ is the inflation rate, $m$ is the stock of real balance holdings and $r$ is the real interest rate.

Maximizing (2) subject to (3), (4) and (5) yields the first-order optimality conditions

$$
\begin{gathered}
u_{c}(c, m)-\lambda=0 \\
-\lambda\left(f^{\prime}(k)+\pi\right)=0 \\
\dot{\lambda}=-\lambda\left(f^{\prime}(k)-\theta(k+m)\right)
\end{gathered}
$$

where $\lambda$ is the co-state variable. ${ }^{5}$ In the steady state, from (6) and (7)

\footnotetext{
${ }^{4}$ By assumption $u_{c}>0$ and $u_{c c}<0$.

${ }^{5}$ The transversality condition is

$$
\lim _{t \rightarrow \infty} a_{t} \lambda_{t} e^{-\int_{0}^{t} \theta_{v} d v}=0
$$
}




$$
f^{\prime}(k)+\pi=0
$$

The resource constraint is given by ${ }^{6}$

$$
\dot{k}=f(k)-c
$$

implying in the steady state

$$
c=f(k)
$$

At the same time, from (8)

$$
\theta(k+m)=f^{\prime}(k)
$$

and from (3) and (11)

$$
\pi^{*}=\mu
$$

where $\mu$ is the monetary growth rate.

Linearizing around the steady state levels of consumption, real balances and capital $\left(c^{*}, m^{*}, k^{*}\right)$, characterized by (9), (11) and (12) using (13), yields ${ }^{7}$

$$
\left[\begin{array}{ccc}
0 & 0 & f^{\prime \prime} \\
0 & \theta^{\prime} & \rho \\
-1 & 0 & \theta
\end{array}\right]\left[\begin{array}{c}
d c^{*} \\
d m^{*} \\
d k^{*}
\end{array}\right]=\left[\begin{array}{c}
-1 \\
0 \\
0
\end{array}\right] d \mu
$$

The determinant of the coefficient matrix in (14)

$$
|\Delta|=f^{\prime \prime} \theta^{\prime}<0
$$

Therefore, it is possible to determine the effect of monetary growth on steady state consumption

$$
\frac{d c^{*}}{d \mu}=\frac{-\theta \theta^{\prime}}{|\Delta|}>0
$$

on real balance holdings

$$
\frac{d m^{*}}{d \mu}=\frac{\rho}{|\Delta|}<0
$$

and on the capital stock

$$
\frac{d k^{*}}{d \mu}=\frac{-\theta^{\prime}}{|\Delta|}>0
$$

Monetary growth substitution effects lower the initial value of real wealth and raise the opportunity cost of holding real balances. This reduces steady state real balance holdings and the rate of time preference, but raises savings. Endogenous time preference wealth effects reinforce the substitution effect and transform the added savings into steady state consumption and capital. The Mundell-Tobin effect is the result of reinforcing wealth and substitution effects and is generated without any counterintuitive preference assumptions. ${ }^{8}$

\footnotetext{
${ }^{6}$ Depreciation of capital has been removed with no loss of generality.

${ }^{7} \rho=\theta^{\prime}-f^{\prime \prime}>0$.

${ }^{8} \mathrm{Kam}$ (2002a) demonstrates that assuming the rate of time preference is an increasing function of real wealth implies stability.
} 


\section{The Representative Agent Model with Endogenous Time Pref- erence and a Cash-in-Advance Constraint}

Stockman models a cash-in-advance constraint that applies to the purchase of capital and consumption goods. In continuous time, this constraint becomes

$$
m_{t}=c_{t}+\dot{k}_{t}
$$

Substituting (4) into (3) and (19) gives the constraints

$$
\dot{k}_{t}=\left(a_{t}-k_{t}\right)-c_{t}
$$

and

$$
\dot{a}_{t}=f\left(k_{t}\right)+x_{t}-c_{t}-\pi\left(a_{t}-k_{t}\right)
$$

The representative agent maximizes (2) subject to (5), (20), (21) and the stock budget constraint

$$
\lim _{t \rightarrow \infty} k_{t} e^{-\int_{0}^{t} r_{v} d v} \geq 0
$$

yielding the first-order optimality conditions

$$
\begin{gathered}
u_{c}(c)-(\psi+\gamma)=0 \\
\gamma \theta(k+m)-\psi\left(f^{\prime}(k)+\pi\right)+\gamma=\dot{\gamma} \\
\psi \theta(k+m)+\psi \pi-\gamma=\dot{\psi}
\end{gathered}
$$

where $\psi$ and $\gamma$ are co-state variables. ${ }^{9}$

In the steady state, it must be that

$$
\gamma \theta(k+m)-\psi\left(f^{\prime}\left(k^{*}\right)+\pi\right)+\gamma=0
$$

from (24) using $\dot{\gamma}=0$,

$$
\psi \theta\left(k^{*}+m^{*}\right)+\psi \pi-\gamma=0
$$

from (25) using $\dot{\psi}=0$, and

$$
c^{*}=m^{*}
$$

from (4) and (20) using $\dot{k}=0$. Again linearizing around the steady state $\left(c^{*}, m^{*}, k^{*}\right)$, now characterized by (11), (23), (26), (27) and (28) using (13), yields ${ }^{10}$

\footnotetext{
${ }^{9}$ The transversality condtions are

$$
\begin{aligned}
& \lim _{t \rightarrow \infty} k_{t} \gamma_{t} e^{-\int_{0}^{t} \theta_{v} d v}=0 \\
& \lim _{t \rightarrow \infty} a_{t} \psi_{t} e^{-\int_{0}^{t} \theta_{v} d v}=0
\end{aligned}
$$
}

${ }^{10}$ Let $\alpha=\mu \theta^{\prime}-\lambda f^{\prime \prime}>0$. 


$$
\left[\begin{array}{ccccc}
u_{c c} & 0 & 0 & -1 & -1 \\
0 & \alpha & \gamma \theta^{\prime} & (1+\theta) & -\left(f^{\prime}+\mu\right) \\
0 & \psi \theta^{\prime} & \psi \theta^{\prime} & -1 & (\theta+\mu) \\
-1 & f^{\prime} & 0 & 0 & 0 \\
-1 & 0 & 1 & 0 & 0
\end{array}\right]\left[\begin{array}{c}
d c^{*} \\
d k^{*} \\
d m^{*} \\
d \gamma \\
d \psi
\end{array}\right]=\left[\begin{array}{c}
0 \\
\psi \\
-\psi \\
0 \\
0
\end{array}\right] d \mu
$$

The determinant of the coefficient matrix in (29)

$$
\begin{gathered}
|A|=\left(\alpha(\theta+\mu)+\psi \theta^{\prime}\left(f^{\prime}+\mu\right)\right)+\left(\alpha+\psi \theta^{\prime}(1+\theta)\right) \\
+f^{\prime}\left[\left(\gamma \theta^{\prime}(\theta+\mu)+\psi \theta^{\prime}\left(f^{\prime}+\mu\right)\right)+\gamma \theta^{\prime}+\psi \theta^{\prime}(1+\theta)\right]>0
\end{gathered}
$$

Thus, the effect of monetary growth on steady state consumption is

$$
\frac{d c^{*}}{d \mu}=\frac{-\psi\left(f^{\prime}\right)^{2}}{|A|}<0
$$

on real balance holdings is

$$
\frac{d m^{*}}{d \mu}=\frac{-\psi\left(f^{\prime}\right)^{2}}{|A|}<0
$$

and on the capital stock is

$$
\frac{d k^{*}}{d \mu}=\frac{-\psi\left(f^{\prime}\right)}{|A|}<0
$$

If the rate of time preference is modeled as an increasing function of real wealth and is combined with a cash-in-advance constraint that applies to purchases of consumption and capital goods, monetary growth lowers steady state consumption, real balances and capital. Thus, endogenous time preference has no effect on Stockman's exogenous time preference result that monetary growth is inversely related to steady state capital accumulation.

The reversal of the Mundell-Tobin effect can also be demonstrated using steady conditions (11) and $(28)$

$$
f\left(k^{*}\right)=m^{*}=c^{*}
$$

or, steady state output, real balances and consumption are equal. Substituting (47) into (1)

$$
\beta(v)=\int_{0}^{t} \theta_{v}\left(k_{v}+f\left(k_{v}\right)\right) d v
$$

Comparing (1) and (34) demonstrates that the rate of time preference, first modeled as an increasing function of real wealth, is changed into a function that depends only on the capital stock. Although monetary growth initially raises savings, the cash-in-advance constraint effect directs savings away from the accumulation of steady state consumption and capital. 
The results of the paper are summarized below:

\begin{tabular}{|c|c|c|c|}
\hline \multirow{2}{*}{ Approach } & \multicolumn{3}{|c|}{ Effect of an increase in monetary growth on steady state } \\
\cline { 2 - 4 } & $\mathrm{c}$ & $\mathrm{m}$ & $\mathrm{k}$ \\
\hline \hline NO CIA & - & - & - \\
\hline CIA & + & - & + \\
\hline
\end{tabular}

The effects of monetary growth are determined by the relative magnitude of diverging effects. The cash-in-advance constraint applies to purchases of consumption and capital goods, which levies an investment tax that directs savings away from the accumulation of steady state capital and consumption. Endogenous time preference wealth effects convert savings from real balance holdings into consumption and capital. The cash-in-advance constraint effect dominates endogenous time preference wealth effects so that monetary growth has the net effect of reducing steady state consumption and capital.

\section{Conclusions}

This paper examines the monetary growth effects of combining an endogenous rate of time preference that is modeled as an increasing function of real wealth and a continuous-time representation of Stockman's cash-in-advance constraint on consumption and capital purchases. The result is that monetary growth lowers steady state consumption and capital, which reverses the real implications of the Mundell-Tobin effect.

As the cash-in-advance constraint applies to purchases of consumption and capital goods, it imposes a second constraint on the evolution of the capital stock, which implies equality across steady state real balances, output and capital. The rate of time preference, initially an increasing function of real wealth, is transformed into a function that depends solely on capital. This nullifies endogenous time preference wealth effects so that monetary growth affects real variables through a substitution effect that raises savings and a cash-in-advance constraint that directs savings away from steady state consumption and capital. 


\section{References}

[1] Begg, D. (1980), "Rational expectations and the non-neutrality of systematic monetary policy," Review of Economic Studies 47, 293-303.

[2] Blanchard, O. J., and S. Fischer, Lectures On Macroeconomics (Cambridge, MA: MIT Press, 1989).

[3] Dornbusch, R. and J. Frenkel (1973), "Inflation and Growth: Alternative Approaches," Journal of Money, Credit and Banking 5, 141-56.

[4] Epstein, L., and Hynes, J. A. (1983), "The rate of time preference and dynamic economic analysis," Journal of Political Economy 91, 611-35.

[5] Kam, E. (2002), "Endogenous time preference and the microeconomic foundations of the Mundell-Tobin effect," Ryerson University, Department of Economics Working Paper 26, 112.

[6] Laidler, D.E.W. (1969), "Money, wealth and time preference in a stationary economy," Canadian Journal of Economics 4, 526-535.

[7] Mundell, R. A. (1963), "Inflation and real interest." Journal of Political Economy 71, 280-83.

[8] Rapach, D. E. (2003), "International evidence on the long-run impact of inflation," Journal of Money, Credit and Banking (forthcoming).

[9] Shrestha, K., S. S. Chan, and C. F. Lee (2002), "Are expected inflation and expected real rates negatively correlated? A long-run test of the Mundell-Tobin hypothesis," Journal of Financial Research 25(3), 305-20.

[10] Sidrauski, M. (1967a), "Rational choice and patterns of growth in a monetary economy," American Economic Review Papers and Proceedings 57, 534-44.

[11] — (1967b), "Inflation and economic growth," Journal of Political Economy 75, 796-810.

[12] Stockman, A. C. (1981), "Anticipated inflation and the capital stock in a cash-in-advance economy," Journal of Monetary Economics 8, 387-93.

[13] Tobin, J. (1965), "Money and economic growth," Econometrica 33, 671-684.

[14] Uzawa, H., "Time preference, the consumption function, and optimal asset holdings," In Value, Capital and Growth: Essays in Honor of Sir John Hicks, ed. J. N. Wolfe. (Chicago, IL: Aldine, 1968).

[15] Wang, P. and Yip, C. K. (1992), "Alternative Approaches to Money and Growth," Journal of Money, Credit and Banking 24, 553-62.

[16] Woodward, G. T. (1992), "Evidence on the Fisher effect for U.K. indexed bonds," Review of Economics and Statistics 72, 315-20. 